\title{
题
}

\section{Ethical decision-making: the doctrine of sin and grace}

\author{
S.P. Giles \\ School of Ecclesiastical Science \\ Potchefstroom Campus \\ North-West University \\ POTCHEFSTROOM \\ E-mail: sgiles@telkomsa.net
}

\begin{abstract}
Ethical decision-making: the doctrine of sin and grace

Ethical decision-making presupposes the possession of a free will. Central to a discussion on reformed ethics is the question of the bounds of freedom of the will. The reformed tradition, along with the wider Christian tradition, affirms that the will is not free in the Pelagian sense of being absolutely free, but is constrained by the effects of humanity's fall from original righteousness. This ariticle considers the nature and extent to which the will is considered free, or no longer free at all. The question posed here, within the reformed theoretic ethical framework, is whether the will is so vitiated that a person is incapable of any effective choice of action or inaction in the face of any moral dilemma, or does fallen humanity still possess some ability to make a free choice, albeit under conditions of impaired freedom of the will?
\end{abstract}

\section{Opsomming}

\section{Etiese besluitneming: die leer van sonde en genade}

Etiese bes/uitneming vooronderstel die besit van 'n vrye wil. Die kernvraag van die gereformeerde etiek behels die grense van sodanige vrye wil. Sowel die gereformeerde as die breër Christelike tradisies bevestig dat die wil nie in die Pelagiaanse sin van absolute vryheid vry is nie, maar dat dit bedwing word deur die mensdom se val van sy oorspronklike regskapenheid. Hierdie artikel ondersoek die aard en omvang waarin die wil as vry geag word en of die wil hoegenaamd nog vry is. Die vraag wat hier binne die gereformeerde teoreties-etiese raamwerk gestel word, is of die wil sodanig besmet is dat die besmetting die mens sy vermoë ontneem het om enige doelmatige keuse van 
optrede, of gebrek daaraan, uit te oefen; en of die gevalle mens nog steeds in 'n mate die vermoë beskik om 'n vrye keuse uit te oefen, selfs onder die voorwaardes van 'n beskadigde vryheid van die wil.

\section{Introduction}

It is possible to remain within the reformed tradition without prejudice to membership of this tradition so long as one can affirm, solo Christo, sola fide, sola gratia, sola scriptura, as taught in the Forms of unity and the catechisms. One can also remain within the reformed fold if one affirms that the will is either so totally ruined that a person can make no meaningful choice, or that the will is indeed ruined, but a person, under certain conditions, can make meaningful choices. In the face of divergent reformed opinion on the bounds of the will, and so as to establish some degree of certainty about man's ethical abilities, the author of this article will argue that under certain constraints, fallen humanity, degenerate and regenerate alike, is possessed of a freedom with respect to ethical decision-making.

\section{Free will, bonded will}

When moral conflicts arise between gospel and constitutional imperatives the reformed tradition considers these moral dilemmas from within its proper ethical parameters. These reformed parameters comprise principally: Calvin and his successors' theologies, reformed creeds and catechisms, and acts of synod, the gauge of which is God's will infallibly revealed in sacred Scripture.

Under consideration in this article is inter alia the understanding of two interrelated Christian concepts: the fall, and the will. The reformed doctrine of the fall, and its consequences for the will, are pivotal to an understanding of the process of resolution of moral dilemmas within the reformed theoretical framework of ethics. Undifferentiated fallen humanity's capacity to make decisions in the face of choices between moral good and evil, good and good, and evil and evil, is a moot point with reformed theology and ethics. The debate centres on the modes of God's graceful dealings with the regenerate and unregenerate alike, to be precise, the acceptance or denial of the doctrine of common grace. It is possible to accept or deny the doctrine of common grace within the reformed tradition and remain within it as it is likewise possible to hold the doctrine of supralapsarianism and infralapsarianism and remain reformed. 
By God's grace, argues Abraham Kuyper, all rational human beings, regenerate and unregenerate, are capable of making and indeed do make moral decisions within diverse ethical theoretical frameworks with regard to, for example, the common good (Kuyper, A. 1903: 238-243). Kuyper maintains that God ceaselessly involves himself in the world and in the lives of the regenerate and unregenerate alike, and this, with regard to the unregenerate, God effects by common grace.

Gemeene gratie [...] heeft alleen een negatief doel t.w. de volledige ontwikkeling van het gif der zonde te stuiten. Naar dit tweërlei doel is, zijn ook de middelen, en zulks wel in dien zin, dat de middelen der gemeene gratie nooit iets positief ten leven in den dooden zondaar kunnen uitwerken; maar dat ze zeer wel bij de bekeering kunnen invloeien. (Kuyper, 1903:243.)

Some scholars, within reformed ethics and theology, however, represented by Herman Hoeksema, for one, deny that the apparent morally good actions of the unregenerate are in fact so, as they are not beneficiaries of particular grace for a particular people. From a radical supralapsarian standpoint, Hoeksema maintains that God is ceaselessly active in preserving the sinful condition of the unregenerate (Hoeksema, 2004, 1:236-237). This article addresses these divergent doctrinal opinions.

To highlight the distinctive reformed doctrine of the will, and its implications for ethical decision-making, as and when appropriate, useful reference is made to the Roman Catholic doctrine of the will. This comparison is valuable, since the reformed theological tradition defines itself over and against the Roman tradition. Comparing and contrasting these doctrines of the fall and the will is an aid in understanding the extent to which fallen humanity is totally depraved with respect to the will, which in turn, determines the understanding of fallen humanity's ethical capacity. The relevant debate within the reformed theoretical framework of ethics is the degree to which human nature is vitiated, and the extent to which this vitiation impairs ethical decision-making and moral choice among the regenerate and unregenerate alike.

\subsection{Free will, bonded will: a reformed perspective}

Throughout his writings, Calvin intermittently protests that he is not overly concerned about the use of words "providing a sound understanding of the reality is retained" (Calvin, 1996:69). Reformed theology's understanding of the fall accords with other Christian tradi- 
tions' understanding of Genesis 3, that Adam and Eve, man's first parents, lived in total harmony with God until they voluntarily succumbed to the serpent's temptation to equality with God. Reformed theology holds that this act of disobedience destroyed the necessary condition for free will, i.e. the total harmony between God's will and man's will. Calvin, then, holds the will to be no longer free but bound by sin's fetters (Calvin, Inst. 2.2.7; 1960:249-250). In his treatise, "The bondage and liberation of the will", Calvin declares freedom and bondage to be mutually contradictory (Calvin, 1996:68). Contrariwise, Roman Catholic doctrine states that after the fall, man's will is free, but now, because enslaved to sin, it is limited and fallible (Roman Catholic Church, 2001, Art. 1739:389).

Calvin, therefore, avoids the term "free will" scrupulously, for he fears that understanding of sound reality cannot be safeguarded. "But how many men are there, I ask, who when they hear free will attributed to man do not immediately conceive him to be master of his own mind and will, able of his own power to turn himself to either good or evil?" (Calvin, 1996:69). Here, as ever, Calvin is alert to Pelagianism and its variants. These hold man is born in original innocence, and by the act of his proper will, and independently of God's grace, is able to turn from sin to God. The Council of Orange (AD 529) condemned this doctrine, affirming original sin, and confirming that God's grace, of necessity, precedes man's turning from sin to God.

Henceforward, the term will rather than bonded will or unfree will is used, and is understood in the reformed sense as bonded or unfree. Unless otherwise stated, the use of the term free will is understood in the Pelagian sense.

In keeping with other Christian traditions, reformed Christian anthropology posits a correlation between the fall and the will. Adhering to the reformed tradition, the central thesis of this article is that undifferentiated fallen man, notwithstanding his total depravity, retains the inalienable status of the image of God, and a will with the capacity to effect ethical choice. This article considers the correlation between the fall and the will, and how it affects ethical choice.

\subsection{In the beginning: creation}

In order to appreciate the nature and consequence of the fall of man, it is necessary to reflect upon man's prior state of perfection, which is generally termed in the reformed tradition, "original righteousness". The locus for this is the Garden of Eden. 
The concern of Genesis 1-2 is not primarily the created universe with man at its centre and summit. Its interest is the relationship between God the Creator and God's creation. The purpose of which is twofold: to proclaim God the Creator's absolute sovereignty and transcendence over all creation, and his simultaneous immanence within it. Genesis 1-2 establishes the divinely revealed premise that God is Creator of all, subject to no one other, and to no thing other. There is no cooperation or conflict between God and gods; no cooperation or conflict between creating forces; no conflict between opposing moral forces of good and evil. God has no rivals. God alone commands, "Let there be ...; and there was" (Gen. 1:3-26). God alone fashioned man from the dust of the ground and brought him to life (Gen. 2:7). God took counsel with himself only (Gen. $1: 26)$.

God's imminence in creation affirms that God's relationship to man and creation is not remote in nature, for God ties himself to creation by creating man in the image of God. The essential meaning of "created in the image of God" is relational (Gen. 1:26-31; 2:7), and man's task as the image of God can be performed meaningfully only in relationship to God, to man, and to creation because God first establishes a meaningful relationship with man.

Genesis 1-2, then, describes man's God-given dominion over creation and his freedom to act within creation with respect to God his Creator (Gen. 1:28-31; 2:19-20a). However, Genesis 1-2, noticeably does not relate that man's rule over creation establishes man's autonomy with respect to God the Creator, nor with respect to God's creation. The teaching of the first two chapters of Genesis is that man's freedom is not autonomous freedom but theonomous freedom. Man at the dawn of creation is demonstrably free, yet demonstrably dependent upon God, absolutely sovereign. In short, according to Genesis 1-2, man is free not in relation to self, but free in relation to God and creation. Man is dependent upon God for his very existence: "... then the Lord God formed man from the dust of the ground, and breathed into his nostrils the breath of life; and the man became a living being" (Gen. 2:7). "Man is made the servantfriend of God" (Hoeksema, 2004, 1:279). Adam and Eve's freedom is circumscribed by their essentially dependent relationship with God. Created in the image of God, they alone stand in a conscious dependent relationship to God. All else in creation flies, floats, stands, sits, or lies in an essentially unconscious dependent relationship to God. Freedom, as essentially limited by dependence upon another, is relevant to the understanding of the nature of gospel and 
of constitutional imperatives, as it raises the issue of the possibility, or impossibility, of constraints on these imperatives.

\subsection{Original righteousness}

Contending against liberal individualism, the Lutheran theologian, Wolfhart Pannenberg, in his lecture, Human nature and the individual (1977), makes the point: "The image of the individual who takes himself or herself to be the centre of his or her life aptly describes the structure of sin" (Pannenberg, 1977:26). In the setting of the Garden of Eden, Judaeo-Christian anthropology makes the point that a right relation with God aptly describes the structure of man in the image of God.

In what did that right relation with God, original righteousness, consist? Genesis 1-2 gives no theological detail of this state, indicating only that God lived with the first man and woman in mutual harmony. As the image of God on earth, Adam and Eve's rule over creation was exercised as a blessing. Until the moment of the fall, man's first parents knew only the good. "Then the Lord God said, 'See, the man has become like one of us, knowing good and evil'." (Gen. 3:22a.)

\subsubsection{Original righteousness: Calvin}

Commenting on Genesis 1:26, Calvin enumerates some attributes of perfect human nature as follows, "Adam was endued with right judgement, had affections in harmony with reason, had all his senses sound and well-regulated, and truly excelled in every thing good" (Calvin, 1965:94-95). Other qualities proper to man in the unspoilt image of God can be derived from further reading of Calvin's commentary on Genesis 2. Attributed to this state of excellence is "knowledge of him who is the chief good", and true wisdom, prudence, wisdom, obedience, marital harmony (Calvin, 1965:118137).

Institutes (1.15) is devoted to the original state of man before God. In the opening paragraph of this article, Calvin writes, “... among all God's works, here [in man] is the noblest and most remarkable example of his justice, wisdom, and goodness" (Calvin, Inst. 1.15.1; 1960:183). For a deeper understanding of the qualities attached to man as imago Dei, Calvin turns to Christ, the Second Adam, and reflects upon the meaning of the text, "and to clothe yourselves with the new self, created according to the likeness of God in true righteousness and holiness" (Eph. 4:24). In the first place, putting on 
the new man restores to the regenerate, knowledge [of God's will], pure righteousness, and holiness. These qualities do not exhaust the matter. Calvin declares them synecdoche (Calvin, Inst. 1.15.4; 1960:189). Thus, knowledge, righteousness, and holiness have a multitude of facets and manifestations.

\subsubsection{Original righteousness: Forms of unity}

The Belgic Confession, the Canons of Dort, and the Heidelberg catechism take Genesis 1:26-27, man as imago Dei, as their point of departure in considering the several qualities of original righteousness. Bearing in mind that the Forms of unity are by nature concise formulations of faith and belief, and not elaborated theological treatises, they are nevertheless still relatively terse in this respect, confining themselves to bare comment on Genesis 1-2. They affirm God's revelation in Scripture that man, created by God in God's image, was originally created good, and lived in original righteousness before God and in harmony with creation.

The Belgic Confession briefly describes man as "good, righteous, and holy, capable in all things to will agreeably to the will of God" (Belgic Confession, 1999,14:46).

Original righteousness is addressed indirectly by the Heidelberg catechism in answer to the question concerning whether or not God is unjust in requiring man to keep God's law, which of man's proper volition man is incapable of keeping. To which the Catechism answers, "Not at all; for God made man capable of performing it; but man, by instigation of the devil, and his own wilful disobedience, deprived himself and all his posterity of those divine gifts" (Heidelberg catechism, 1999, Q9:46).

The Canons of Dort state, "Man was originally formed after the image of God. His understanding was adorned with a true and saving knowledge of his Creator and of spiritual things; his heart and will were upright, all his affections pure; and the whole man was holy" (Canons of Dort, 1999, 1:48, art. 3-4).

\subsubsection{Original righteousness: Second Helvetic and Westminster Confessions}

The Second Helvetic Confession states tersely, "Man was from the beginning created by God after the image of God, in righteousness and true holiness, good and upright" (Second Helvetic Confession, 1999, 8.1:46). 
The Westminster Confession of Faith succinctly states, "By this [first] sin they [our first parents] fell from their original righteousness and communion with God" (Westminster Confession of Faith, 1999, 6.2:46).

It appears that the qualities describing what it means to be imago Dei living in original righteousness before God, living in total harmony with God's will, and therefore in total harmony with creation, are of secondary theological concern for the Forms of unity, the Second Helvetic Confession, and the Westminster Confession of Faith. Of primary concern is the confession of faith in God the Creator, God freely creating the universe, man created freely in the image and likeness of God, and as God's image on earth, ruling creation in conformity with God's will.

In sum, for the confessions of faith and the catechism cited above, the state of original harmony between God, man, and creation pertained in the Garden of Eden, not because at the centre of Adam and Eve's life was the tree of life, and the tree of knowledge of good and evil, but God, their Creator and life-giver (Gen. 2:9). So long as this comprised the status quo, man dwelt in a state of original righteousness and holiness before, with, and in God.

\subsubsection{Original righteousness: Kuyper, jr.}

Abraham Kuyper, jr., like his elder namesake, a Dutch neo-Calvinist, says little of the qualities attached to original righteousness, and what he does say, he does not derive from Genesis but approaches the issue from a Christological perspective, after the example of Calvin (Inst. 1.15.4; 1960:189-190): "He [Christ] is the source of your life in Christ Jesus, who became for us wisdom from God, and righteousness and sanctification and redemption" (1 Cor. 1:30). Being made righteous before God in Christ, restores to man the qualities attached to original righteousness, namely, true wisdom, and true holiness. "Hij [Adam] was zoo geschapen, dat hij ter wereld kwam als een voor God rechtvaardige, met ware wijsheid en heiligheid. Het was alles aan, in en bij hem" (Kuyper, jr., 1929:81). Of course, only Christ has the fullness of true wisdom and holiness. As Adam was "complete, in himself and with himself", so too is Christ, the Second Adam.

\subsubsection{Original righteousness: Hoeksema}

With regard to man as imago Dei living in harmony with God before the fall, Hoeksema says only, and without further comment or ela- 
boration, "there was a reflection of the perfections of God in man" (Hoeksema, 2004, 1:289).

This lack of interest in the qualities of original righteousness is unsurprising. Hoeksema, along with Bahnsen, Einwechter and Rushdoony, represent a particular school of Calvinism after Calvin that would deny that there is anything, even a slight residue of the image of God left in man totally depraved, if "total depravity" is to retain its meaning. Foundational to Hoeksema's theology of fallen man, and denial of common grace, is a radical definition of the absolute loss of the imago Dei, even going as far as to claim that fallen man bears the image of Satan (Hoeksema, 2004, 1:294).

Calvin does not claim that the imago Satani supersedes the imago Dei. Hoeksema's opinion goes beyond Calvin's overarching view of imago Dei expressed in the Institutes and his commentary on Genesis: "Truly, there are many things in this corrupted nature [of man] which may induce contempt; but if you rightly weigh all circumstances, man is, among other creatures, a certain pre-eminent specimen of Divine wisdom, justice and goodness [...]" (Calvin, 1965: 92).

\subsubsection{Original righteousness: summary}

The term original righteousness is a theological attempt to describe man's original relationship to God when man, possessed of free will, effortlessly projected the image of God. This situation no longer pertains, because the image of God in man, and man's free will, are corrupted, though not totally annihilated. All attempts to speak of the theological facets of imago Dei, therefore, are necessarily impaired because of the fall. Calvin's remark on the true nature of the image of God is relevant in this respect, "it seems that we do not have a full definition of 'image' [of God]", and implies, correctly, that a full definition will never be arrived at (Calvin, Inst. 1.15.4; 1960:189). Reformed theology and doctrine are content to affirm without elaboration that, under the conditions of original righteousness, God's glory shone out in all its fullness in man, and the perfections of God were manifest fully in God's image on earth.

\section{Effect of the fall}

It is beyond the scope of this article to discuss detailed theological differences of opinion posited by various Christian theological traditions on the effect of the fall, specifically, differences between the reformed and the Roman Catholic traditions, in which Calvin 
engaged. However, it is necessary to pay attention to the basic divergence of opinion over the consequences of the fall within the reformed theological tradition, as this article is undertaken from within its parameters.

In his introductory remarks to Genesis 3, Calvin writes, "After he [man] had been deceived by Satan, revolted from his Maker, [man] became entirely changed, and so degenerate, that the image of God in which he had been formed, was obliterated" (Calvin, 1965:139). Here Calvin expresses the consequences of the fall using particular vocabulary. Within the reformed tradition, diverse theological interpretations of Calvin's terminology have caused to appear towards the poles of reformed theology's continuum, notably, Arminianism, and popularly named, Hyper-Calvinism. In addition, misunderstanding outside the reformed tradition, of interest here the Roman Catholic Church, has occurred around Calvin's theological terminology of the fall and its effect on free will.

External to the reformed tradition, it is sufficient to cite one example of the Council of Trent's (1545-1563) 33 anathematising canons on Justification, several of which are anti-Pelagian, and the rest uncompromisingly against the reformers. Germane to this article is Trent, Session 6, Justification, Canon 5, on free will. Here free will is not understood in the Pelagian sense but in the Roman sense as enslaved to sin and therefore limited and fallible. "If any one says, that after the sin of Adam, man's will was lost and destroyed, or that it is a thing only in name, indeed a name without reality, a fiction introduced into the church by Satan: let him be anathema" (Council of Trent, 1978:43). Here Trent has in mind Luther who maintained that, after original sin, free choice is a reality only in the mind. Calvin follows Luther here, and rejects Trent's interpretation and condemnation of Luther.

\subsection{Effect of the fall: problematic terminology}

The stance of Luther and Calvin on the will begs the question of the function, if any, of the will with respect to ethical choice. Arminianism answers this question by affirming man's will is free after the fall. Hyper-Calvinism's affirmation that man is absolutely depraved leads to the conclusion that the will is destroyed. Trent's anathematising response to Luther, Calvin, and the reformers results in part from the vitiation of right theological relationships. Parties in dialogue had become deaf. 
Reformed terminology then, is not without problems. With respect to man's will, terms such as depraved and obliterated need some explanation, as from a reformed perspective at least they appear to be misunderstood. Trent seems to treat Calvin's theological terminology, inter alia, "depraved" and "obliterated", as cognates of "destroyed" or "annihilated", and therefore perceives a denial of free will, albeit defined in the Roman sense as enslaved to sin, fallible and limited.

Furthermore, the wording of article headings, for example, "Only damnable things come forth from man's corrupt nature" (Calvin, Inst. 2.3; 1960:289), may inform an erroneous view that Calvin denies that man is capable of any ethical choice, other than possibly between evil and evil. It should be remembered that Calvin's Institutes, Scripture commentaries, catechisms, and polemical works, were addressed primarily to his followers, and not to his opponents. As Schultz observes with respect to Calvin's treatise on free will, Calvin intended this treatise on free will (as well as that on predestination), for distribution among the faithful: "They were not scientific essays for professionals but expositions for the edification of the church in general" (Schultz, 1971:137). Tempering theological terminology to opposing theological opinion then was not de rigueur in sixteenth century Wittenberg, Geneva, and Rome; nor, because theologians addressed members of their own churches, was it deemed necessary.

The bondage and liberation of the will - a defence of the orthodox doctrine of human choice against Pighius (1543) - hardly indicates willingness to dialogue with the Dutch Roman Catholic theologian, Albert Pighius. Then Calvin's opponents acted likewise, Pighius being a prime example. Pighius', ten books on human free choice and divine grace (1542), is a forthright attack on two articles of the Institutes (1539), namely, "The knowledge of humanity and free choice", and, "Predestination and providence of God".

\subsection{Effect of the fall: attempting an understanding of the terminology}

Reformed theology discusses fallen man's predicament in terms of imago Dei, and the nature and extent of the bondage of the will, in preference to Trent's theology of man as imago Dei, and the nature and extent of man's will defined as free to whatever slight degree. Calvin's stated reluctance to use "free will", and his preference for "bondage of the will", is helpful in considering constraints inhibiting man's choice between good and evil, good and good, and evil and 
evil. It also maintains the status and necessity of God's prevenient grace affirmed by the Council of Orange.

It ought to be acknowledged, however, that Calvin's theological terminology of the fall opens itself to the possibility, within and outside the reformed tradition, of an unjustifiably pessimistic view of man's radical depravity and ethical ability. As noted previously, Calvin does not intend that man's total depravity be considered a cause for pessimism (Calvin, Inst. 1.1.1; 1960:35-37). Such gloomy anthropology may originate from a consideration of man's sinful acts, which admittedly, arguably reflect the imago Satani, rather than project the imago Dei. This may lead to the hypothesis that man is incapable of making any meaningful ethical decision in any sphere of life, religious or civic. Man's manifest penchant to sin does not imply that the reality of his ontological status as the image of God, albeit corrupted, or deformed, or obliterated, is ever forfeit to Satan.

Calvin does not intend his theological terminology of the fall and its consequences to be defined or interpreted as nihilist. Indeed, Calvin is anxious to maintain this point throughout his work, for example:

There is no doubt that Adam, when he fell from his state, was by this defection alienated from God. Therefore, even though we grant that God's image was not totally annihilated and destroyed by him, yet it was so corrupted that whatever remains is frightful deformity. (Calvin, Inst. 1.15.4; 1960:189.)

That man definitely retains some degree of his God-given endowments inter alia, wisdom, reason, and will, is specifically dealt with by Calvin (Inst. 2.12-17; 1960:464-534).

\subsection{Effect of the fall: summary}

Affirming that man retains something of God's gifts of nature does not lessen the gravity of man's fall from his original state of righteousness before God and his harmonious relationship to creation. Nor does it imply that man, of his proper volition, can do any good towards God that will earn him salvation. The real tragedy of the fall of man from original righteousness, true wisdom, and holiness is a double one. The shattering of the image of God in man, and the ruination of the original harmonious relationship willed by God, means not only that man no longer reflects the full glory of God, whose image he is, but that God no longer sees the fullness of his glory shining forth from man freely created in the image of God. 
The fundamental reality and misfortune of man's total depravity is his vitiated relationship with God. Nevertheless, in the face of this, reformed anthropology insists on common humanity's essential and irrevocable status as imago Dei. Man's deeds, good, bad, and indifferent, are important but of secondary concern. Reformed anthropology further maintains that under common grace, undifferentiated humanity is indeed capable of deeds that benefit the common good of society.

In sum, the consequence of the fall and man's total depravity ought not to shoulder a greater burden than Calvin lays upon it. The imago Dei is adjectivally qualified as corrupted, and deformed, and obliterated. Calvin's grammar of the fall unfortunately leaves itself open to unintended theological interpretation. Writing from within the reformed tradition, one must take Calvin's corpus in its entirety, which affirms that undifferentiated fallen man retains his will to a degree. Pertinent to this article is the nature and parameters of the will with respect to ethical choice.

\section{Free will: its nature and reach}

Arguably, free will, by whatever criteria, is a misnomer, for in practice the will is never free, but bound. The Judaeo-Christian tradition affirms that Adam and Eve possessed free will. Their will was deemed free as long as it remained in harmony with God's will. Even in this state of original righteousness, however, Adam and Eve's wills were not autonomous, but mutually bound to God, each other, and the rest of creation. But man freely changed this relationship by sin, and ipso facto, the conditions of the bound will. In sum, both graceful and sinful relations constrain freedom.

In the theonomous sphere, under consideration here the JudaeoChristian tradition, God periodically binds fallen man's freedom with respect to himself - Noah (Gen. 9:1-7), Abram (Gen. 15), Moses (Ex. 20:1-21). God also charges Israel never to forget this covenant dependence and necessary obedience to God's will (Deut. 6:1-9). The Pentateuch extensively details practical constraints placed on man's freedom by duties and obligations towards God and neighbour.

In the Christian milieu, Christ, in his proper person, is confessed as the hoped for fulfilment of God's promised new covenant (Jer. 31:31-37). Attachment to Christ circumscribes man's freedom, and further extends the reach of obligations set forth in Deuteronomy 6:1-9 and detailed in the Pentateuch. Christian discipleship means 
putting God, through, with, and in Christ, first in all things, and even putting one's neighbour before oneself, albeit at some considerable personal cost (Rom. 15:1-6).

In the secular (laïque) sphere, men, not God, limit man's freedom. The constitutions and common law of States attest to this. Thus, a secular hypothesis that man is naturally free in the sense that Stoics claim that freedom is inalienably natural to man, and modern and postmodern claims of radical individuality that posits man's innate freedom with respect only to himself, do not, in practice, give the individual possessed of freedom, so defined, unbounded rights with respect to himself and no other.

In sum, from the reformed Christian theological perspective, theology attests that God first established his relationship with man, and by this creative act, God's freedom is freely bound. Created in God's image, fallen man's freedom is likewise bound by relationships, whether to sin or by particular grace to God in Christ, or, by common grace to one another and the totality of creation.

\subsection{Bonded will: its nature and reach - Forms of unity}

There is uniform reformed agreement concerning the nature of fallen man's will, namely, that it is depraved, bonded to evil and incapable of any good towards salvation. The Forms of unity address the issue of fallen man's nature thus. The Canons of Dort state that by an act of man's free will, God's outstanding gifts pertaining to original righteousness were replaced by "blindness of mind, horrible darkness, vanity and perverseness of judgment, became wicked, rebellious, and obdurate in heart and will and impure in his affections" (Canons of Dort, 1999, 1:48, art. 3-4.). Having lost God's excellent gifts by sin, affirms the Belgic Confession "[Man has] thus become wicked, perverse, and corrupt in all his ways" (Belgic Confession, 1999, 14:46). And, in answer to the Heidelberg catechism's question on man's ability to keep God's law perfectly, the Heidelberg catechism affirms, "In no wise, for I am prone by nature to hate God and my neighbour" (Heidelberg catechism, 1999, Q5:46).

\subsection{Bonded will: its nature and reach - Second Helvetic and Westminster Confession}

The Second Helvetic Confession is more fulsome in its statement on the fall of man, and the cause of sin. 
Man was from the beginning created by God after the image of God, in righteousness and true holiness, good and upright; but by the instigation of the serpent and his own fault, falling from the goodness and unrighteousness, he became subject to sin, death and diverse calamities; and such a one he became by his fall, such are all his offspring, even subject to sin, death and sundry calamities. (Second Helvetic Confession, 1999, 8.1:46.)

On the fall of man, and man's punishment consequential thereupon, the Westminster Confession of Faith confines itself to this cryptic formulation. "By this [first] sin they [our first parents] fell from original righteousness and communion, with God, and so became dead to sin, and wholly defiled in all their parts and faculties of soul and body." (Westminster Confession of Faith, 1999, 6.2:47.)

In sum, for these five reformed confessions of faith, original sin definitively bound man's will.

\subsection{Bonded will: its nature and reach - Calvin}

Calvin's doctrine of total depravity of the will that is foundational to all reformed opinions concerning fallen man's nature and will has been systematically referred to throughout this article thus far. It may be summarised accordingly as, "sin overturns the whole man" (Calvin, Inst. 2.1.9; 1960:266-267). Consequently, "Man cannot ascribe to himself even one single good work apart from God's grace" (Calvin, Inst. 2.3.12; 1960:306).

\subsection{Bonded will: its nature and reach - Kuyper, jr.}

Kuyper, jr. discusses man's nature in its narrower sense (engeren Zin), and wider sense (ruimeren Zin). After the fall, man lost true knowledge, righteousness, and holiness; thus, man's nature in the narrow sense was lost. Man, however, retained his nature in the wider sense, attested by the vestige of knowledge, reason, and wisdom (Kuyper, jr., 1929:126-127). Kuyper, jr. affirms the irrevocable (onverliesbaar) status of man in the image of God, and that man's status of imago Dei is never forfeit to Satan. Man's will is bound to sin, not to Satan.

\subsection{Bonded will: its nature and reach - Hoeksema}

On man's nature, Hoeksema avoids speaking in terms of man in the image of God, and speaks of man as man. "He is man in the state of rectitude. He remains man when he falls. And he is still man when he is regenerated." (Hoeksema, 2004, 2:148). Retaining some 
knowledge of earthly things, Hoeksema states that fallen man's nature

... spiritually and ethically was put into reverse. His knowledge became darkness and the lie, his righteousness was changed into unrighteousness and iniquity, and his holiness became hatred of the living God ... He loves sin with all his heart and follows it all his life. He is an enemy of God who minds and wills sin. (Hoeksema, 2004, 1:152-153.)

\subsection{Bonded will: its bounds}

According to reformed theology, the will is only free when it is truly aligned with God's will. "In general, freedom is the state in which man's inner nature is in perfect accord with the law of God." (Hoeksema, 2004, 1:300.) Since the fall, this original total harmony of wills no longer pertains. The will, says Calvin in his reply to Pighius on human choice, is now bonded to evil. "A bound will, finally, is one which, because of its corruptness, is held captive under the authority of evil desires, so that it can choose nothing but evil." (Calvin, 1996:69.)

The reformed use of bonded will rather than free will, principally due to inherent associations with Pelagian claims of man's ability to turn from sin to God by sole use of his unfettered will, still leaves the issue of the extent of bounds of the bonded will, and their effect as a constraint on his ethical decision-making. Reformed opinion diverges regarding the extent of the influence of man's bonded will on his ethical decision-making capacity. This raises the issue of how strongly bound to all evil is the bonded will? In the light of Calvin's uncompromising condemnation of Pelagianism in his reply to Pighius, and reiterated elsewhere in Calvin's writings, and echoed throughout reformed theology, the answer to this question is that the will is solidly bound to all evil.

It is of importance, however, that this answer does not exclude the action of God's grace. The reformed categorical reply allows for the operation of the Holy Spirit, be that the working of particular grace in particular people, or the operation of common grace for the common good. As difficult as it is to recognise under the conditions of total depravity, God continues to maintain his intimate and influential sustaining relationship with fallen man and the fallen world. "God, whenever He wills to make way for his providence, bends and turns men's wills even in external things; nor are they so free to choose 
that God's will does not rule over their freedom." (Calvin, Inst. 2.4.7; 1960:315.)

Thus, reformed theology asserts the robust bounds of man's will corrupted and bound to all evil. However, the will does not operate in isolation from fallen man as an entity per se. The will is integral to man as imago Dei, and as such, is an essential constituent of man's entire relationship to God. God, accordingly, through his graceful relationship with man and the rest of creation, is freely able to modify the internal and external parameters under which the bonded will operates. The answer then to the question of the parameters of the bounds of the will bound to all evil, is the freedom of God the Creator in relation to fallen man, God's creature. In other words, reformed theology affirms that under the constraint of sin, and the liberty of God's grace, the will indeed has the capacity to effect ethical choice. And, that against Pighius, the doctrine of the bonded will does not imply determinism, which necessarily entails the suspension of human responsibility, thus rendering all human activity senseless (Schultz, 1971:36).

\section{Free will - bonded will: summary}

The issue of the nature and bounds of man's will arises in reformed and Roman traditions. The reformed tradition's doctrine of the fall, and its effect on the will regarding ethical decision-making, is so formulated as to refute unambiguously all Pelagian and semi-Pelagian doctrines of sin and free will. The Roman tradition, in expounding its doctrine of the fall, does not systematically reiterate its opposition to the doctrines of Pelagianism and semi-Pelagianism. Rome presupposes that one reads its theology of the fall and free will within tradition, i.e. Scripture, the Early Fathers, councils; and here specifically, the canons of the Council of Orange, and Trent's reaffirmation of these by the decree concerning original sin (Council of Trent, 1978: Session five).

Reformed, and Roman terminologies, are avowedly anti-Pelagian, and both are open to interpretations other than intended. Rome's doctrine of free will taken out of context, i.e. tradition, leads to the accusation that man, solely by the power of his will, is capable of turning from sin to God. The reformed doctrine of the bonded will, in conjunction with the doctrine of man's total depravity, taken out of the context of particular and common grace, leads to the assumption that man has no choice in matters ethical, or if he has a choice, only between evil and evil. The denial by some reformed schools, of common grace, likewise leads to an unintended pessimistic view of 
man that negates his God-given irrevocable status of imago Dei to an irrelevance with respect to ethical decision-making, and consequently imposes limits to his ethical ability beyond those Calvin intended.

Optimistically, reformed theology affirms that the limits to man's will, and hence man's ethical ability, is ultimately determined by his dependence on God, and not upon his bondage to sin, and even less upon the power of Satan; for the whole person is bound to sin, not to Satan. Original sin manifestly ruined man's harmonious relationship to God, but did not annihilate it. Further, man is not immune from Satan's temptation to sin. It is within this matrix of sin and grace that fallen man exercises his will and ethical ability. Alternatively, now that sound understanding of the reality of free will is here established, one may say that fallen man exercises his free will and ethical ability within this matrix of sin and grace.

To conclude, the valid reformed position of radical supralapsarianism notwithstanding, the balance of the reformed ethical tradition affirms that the regenerate and unregenerate alike are not so bound to sin that they are rendered incapable of meaningful ethical decisions in the face of moral dilemmas. The reformed theoretical framework of ethics acknowledges that moral choices are a practical possibility, be it through the activity of particular grace for the regenerate, or common grace for the unregenerate. This article accepts that man is in possession of an impaired moral faculty that is nevertheless capable of grasping universal ethical implications of moral dilemmas.

\section{List of references}

BELGIC CONFESSION. 1999. (In Beeke, J.R. \& Ferguson, S.B., eds. Reformed confessions harmonized. Grand Rapids: Baker. p. 2-244.)

BIBLE. 1989. New revised standard version. Grand Rapids: Zondervan.

CALVIN. 1960. Calvin: institutes of the Christian religion. Vol. 2. Ed. by J.T. McNeill. Philadelphia. Westminster.

CALVIN. 1965. Genesis. Ed. and trans. by J. King. Edinburgh: The Banner of Truth Trust.

CALVIN. 1996. The bondage and liberation of the will - a defence of orthodox doctrine of human choice against Pighius. Ed. by A.N.S. Lane. Trans. by G.I. Davies. Grand Rapids: Baker.

CANONS OF DORT. 1999. (In Beeke, J.R. \& Ferguson, S.B., eds. Reformed confessions harmonized. Grand Rapids: Baker. p. 2-244.)

COUNCIL OF TRENT. 1978. (In Schroeder, H.J. Canons and Decrees of the Council of Trent. English translation. Rockford: Tan Books. 
ENGELSMA, D.J. 1994. Hyper-Calvinism the call of the gospel: an examination of the "well-meant offer" of the gospel. Grand Rapids: Reformed Free Publishing Association.

HEIDELBERG CATECHISM. 1999. (In Beeke, J.R. \& Ferguson, S.B., eds. Reformed confessions harmonized. Grand Rapids: Baker. p. 2-244.)

HOEKSEMA, H. 2004. Reformed dogmatics. 2nd ed. Vol. 2. Grand Rapids: Reformed Free Publishing Association.

KUYPER, A. 1903. De gemeene gratie: het leerstellig gedeelte. Deel 2. Amsterdam: Höveker \& Wormser.

KUYPER, A., jr. 1929. Het beeld Gods. Amsterdam: De Standard.

PANNENBERG, W. 1977. Human nature, election, and history. Philadelphia: Westminster.

ROMAN CATHOLIC CHURCH. 2001. Rev. ed. Nairobi: Paulines.

SCHULZE, L.F. 1971. Calvin's reply to Pighius. Potchefstroom: Pro Rege.

SECOND HELVETIC CONFESSION. 1999. (In Beeke, J.R. \& Ferguson, S.B., eds. Reformed confessions harmonized. Grand Rapids: Baker Books. p. 2-244.)

WESTMINSTER CONFESSION OF FAITH. 1999. (In Beeke, J.R. \& Ferguson, S.B., eds. 1999. Reformed confessions harmonized. Grand Rapids: Baker Books. p. 2-244.)

\section{Key concepts:}

ethical decision-making

fall

ethics, reformed

will

\section{Kernbegrippe:}

etiese besluitneming

etiek, gereformeerde

sondeval

wil 
